\title{
MENINGKATKAN PENDAPATAN MASYARAKAT MELALUI PEMBENTUKAN BANK SAMPAH
}

\author{
Dewi Saptantinah $\mathbf{P}^{1}$, Fadjar Harimurti ${ }^{2}$, \\ ${ }^{1,2)}$ Fakultas Ekonomi \\ Universitas Slamet Riyadi Surakarta
}

\begin{abstract}
Abstrak
Masalah sampah merupakan masalah yang sulit dicari solusinya., hal ini semakin bertambah apabila penduduk semakin padat. Untuk mengatasi masalah tersebut perlu diatasi dengan memanfaatkan barang yang tidak terpakai tersebut menjadi produk yang dapat dimanfaatkan. Hal ini dapat dilakukan atas partisipasi masyarakat sekitar. Dari hasil kreatifitas tersebut dapat diwadahi dalam bank sampah, yang dapat menampung dan memilah sampah, kemudian dijual atau dibuat kreatifitas berbagai asesoris dan hasilnya dapat untuk meningkatkan pendapatan. Dengan demikian perlu dibentuk adanya bank sampah. Hal ini juga dilakukan di perumahan Joho baru Sukoharjo, yang mayoritas penduduk sekitar adalah perumahan. Dengan dibentuknya bank sampah maka dapat mengelola kegiatan tersebut. Dalam kegiatan pengabdian ini tim kami berusaha untuk memberikan sosialisasi dan penyuluhan pentingnya dibentuk bank sampah. Dalam kegiatan pengabdian ini juga tim kami memfasilitasi adanya peralatan berupa timbangan serta buku harian dan buku besar untuk mencatat transaksi dari hasil penjualan.
\end{abstract}

Kata kunci : Peningkatan pendapatan, Bank Sampah

\section{PENDAHULUAN}

Pada saat ini sampah merupakan masalah utama yang sulit untuk dicari solusinya, dengan semakin padatnya penduduk maka sampah akan menjadi masalah utama, hal ini juga dipengaruhi oleh kesadaran masyarakat dalam membuang sampah serta pengelolaan sampah dari warga sekitar. Permasalahan semakin muncul pada perumahan yang padat penduduk. Hal ini terjadi juga pada Perumahan di Sukoharjo yang menjadi obyek pengabdian ini. Adalah Perumahan Joho Baruterletak di SukoharjoJawa Tengah, yang merupakanperumahan yang luasdenganpenduduk yang padatdengankepadatanpenduduktersebutmakapermasalahan yang utamaadalahpengelolaansampah yang menumpuk di lingkungan. Terkait dengan program kebersihan lingkungan sekitar maka warga di perumahan ini khususnya warga RT 02/09 dengan $\begin{array}{llll}\text { jumlah } & 50 & \text { warga } & \text { ini }\end{array}$ bagaimanasampahtersebutsebaiknyadikelolasehinggamemberikandampak yang positif.Dampak yang diharapkandari pengelolaan tersebut adalah penanganan sampah menjadi produk yang lebih berguna dan dapat digunakan untuk meningkatkan pendapatan keluarga sehingga kegiatan ini adalah menciptakan bank sampah dari yang belum ada diharapkan untuk menjadi ada. 
Kegiatanpengelolaansampahini nantinya akan melibatkan warga masyarakat sekitar dari sampah masing-masing warga dikumpulkan di tempat penampungan, kemudian dipilah-pilah antara sampah organik dan non organik. Untuk sampah non orgaik misalnya berupa kaleng bekas atau plastik kemasan bekasnatau dos-dos bekas ini nanti dijual ke pengepul dengan penilaiannya adalah berdasar berat masing-masing sampah non organik tersebut. Kegiatan ini direncanakan dilaksanakan secara rutin dengan melibatkan warga sekitar. Hasil penjualan tersebut dikumpulkan terlebih dahulu dan tiap akhir periode 1 bulan atau setahun sekali, keuntungan dari penjualan dibagikan kepada pengelola bank sampah. Hal ini akan bermanfaat untuk dapat menambah pendapat masyarakat.

Pengelolaansampahtersebuttergolongsangatprospektifkarenalokasi di daerah perumahan diamana volume sampah rumah tangga cukup banyak. Masalah yang berkaitan dengan pengelolaan sampah terletak pada cara memanfaatkan sampah-sampah tersebut. Pada awal rencana pendirian bank sampah ini kegiatan masih sebatas pada memilah sampah kemudian untuk sampah non organik dijual ke pengepul sampah.

Apabilapengelolaansampahsudah berjalan maka untuk selanutnya perlu dipikirkan juga mengenai pengelolaan adminitrasinya karena dengan terdapatnya hasil penjualan dari sampah non organik ke pengepul sampah maka transaksi sudah mulai berjalan dengan demikian perlu adanya pencatatan mengenai keluar masuknya uang dari kegiatan tersebut, hal ini perlu dipikirkan pula untuk untuk pembukuannya, sehinga apabila bank sampah sudah berkembang maka pembbukuan sudah tertata rapi dan sudah tertib.

Adapundalamperencanaanpendirian bank sampah ini perlu dipikirkan pengadaan peralatan yang diperlukan, dalam hal ini peralatan utama yang sangat diperlukan adalah timbangan karena kegiatan utama bank sampah ini adalah menjual ke pengepul sampah dengan nilai yang dihitungberdasarkanberatdaribarangbekas yang dijual. Sebagai gambaran bahwa Pembentukan Bank Sampah Mawar ini berlokasi di Perumahan Joho Baru Sukoharjo, yang diketuai oleh Bapak Parino. Selama ini kegiatannya hanya menjual sampah anorganik ke pengepul saja. Rencana ke depannya dengan membentuk Bank Sampah maka kegiatannya akan lebih banyak yaitu dengan menjual kerajinan dari hasil kreasi warga dalam mengubah sampah anorganik menjadi berbagai kerajinan dan asesoris.

Permasalahan dalam obyek pengabdian ini ditinjau dari beberapa segi, yaitu dari segi produksi, untuk proses produksi ini belum ada kegiatan sama sekali, karena baru memilah 
sampah organik dan anorganik dan kemudian sampah anorganik dijual kepada pengepul. Fasilitas juga belum memadai karena hanya memanfaatkan lokasi seadanya untuk menampung sampah, tidak ada tempat khusus untuk menampung dan memilahkan sampah organik dan anorganik. Peralatan seperti timbangan belum dimiliki oleh bank sampah ini, hal ini menyulitkan bagi pengelola bank sampah, karena peralatan utama untuk menentukan berat sampah yang akan dijual adalah timbangan. Dari segi administrasi juga masih menjadi masalah karena belum ada catatan keluar masuknya uang tunai dari hasil penjualan.

Dengan demikian dalam program pengabdianmasyarakatinipermasalahan yang diidentifikasiadalahmasihperlunyapengadaanperalatanberupatimbangan dan perlunyapengetahuanmengenaipengelolaan bank sampahsertapenangananpembukuannya. Adapun solusi yang akan kami tawarkan dengan adanya permasalahan di atas adalah memberikanpemahamancarapengelolaansampah dan memberikanbantuanperalatanberupatimbangan. Sedangkan target luarannya adalah bertambahnyakemampuandalammengatasipermasalahansampahwarga dan bertambahnyaperalatan yang dimilikimitra.

\section{METODE PELAKSANAAN}

Ditinjau dari beberapa temuan permasalahan dalam kegiatan pengabdian ini maka metode yang dapat dilaksanakan dalam program pengabdian masyarakat ini adalah dengan cara memberikan penyuluhan dan sosialisasi mengenai pentingnya bank sampah untuk mengatasi permasalahan sampah warga yang menumpuk dan dengan dibuat aneka macam asesoris maka dapat dijual dan dapat meningkatkan pendapatan masyarakat, sehingga tujuan dari sosialisasi ini adalah untuk memberikan pemahaman kepada warga manfaat dari pengelolaan sampah. Kemudian metode kedua, dengan dibantu beberapa peralatan untuk kegiatan bank sampah dan pada akhirnya dilakukan pendampingan dari warga yang membentuk bank sampah ini. Secara ringkas ditunjukkan dalam tabel di bawah ini: 


\section{TABEL 1}

MetodePelaksanaanKegiatan

\begin{tabular}{|l|l|l|}
\hline \multicolumn{1}{|c|}{ PERMASALAHAN } & TARGET DAN LUARAN & \multicolumn{1}{c|}{ KETERANGAN } \\
\hline $\begin{array}{l}\text { Kurangnya pengetahuan } \\
\text { dalam hal pengelolaan }\end{array}$ & $\begin{array}{l}\text { Memberika penyuluhan dan } \\
\text { sosialisasi mengenai } \\
\text { penanganan masalah sampah } \\
\text { warga sehingga dapat } \\
\text { meningkatkan pendapatan } \\
\text { keluarga. }\end{array}$ & $\begin{array}{l}\text { Penyuluhan mengenai } \\
\text { penanganan sampah yang } \\
\text { senumpuk di perumahan } \\
\text { yang positif dan } \\
\text { menghasilkan serta } \\
\text { sosialisasi tentang bank } \\
\text { mengolah sampah }\end{array}$ \\
\hline $\begin{array}{l}\text { Kurangnya peralatan untuk } \\
\text { pengelolaan keuangan }\end{array}$ & $\begin{array}{l}\text { Menambah perlatan berupa } \\
\text { timbangan }\end{array}$ & $\begin{array}{l}\text { Pemberian bantuan peralatan } \\
\text { yang dibutuhkan pengelola }\end{array}$ \\
& $\begin{array}{l}\text { studi banding untuk } \\
\text { pembelajaran kepada calon } \\
\text { pengelolaan bank sampah } \\
\text { sehingga calon pengelola } \\
\text { memahami cara } \\
\text { pengelolaannya. }\end{array}$ & $\begin{array}{l}\text { Pengelolaannya manajemen } \\
\text { bank sampah dan } \\
\text { pengelolaan keuangannya }\end{array}$ \\
\hline
\end{tabular}

Adapun untuk rencana kegiatan selanjutnya adalah mengadakan kegiatan lanjutan untuk meindaklanjuti pembentukan bank sampah ini dengan mengadakan pelatihan tentang administrasi keuangan untuk mengelola pendapatan yang masuk dan apabila diperlukan perlu adanya studi banding ke bank sampah yang sudah maju kegiatan operasionalnya.

\section{KESIMPULAN DAN SARAN}

Kegiatanpengabdianinidilakukan pada bank sampah di perumahan Joho Baru Karanganyar. Bank sampah tersebut bersama tim pengabdian melakukan program kegiatan yang telah direncanakan bersama. Dalam program pengabdian yang dilakukan, kegiatan -kegiatan 
yang dilakukan meliputi penanganan masalah-masalah bank sampah terdiri dari masalah kurangnya pengetahuan dan wawasan dalam mengolah sampah serta kurangnya peralatan untuk mendaur ulang pada bank sampah mitra.

Adapun saran yang dapat diberikan dari kegiatan ini adalah, kegiatanpengabdianinisinergiantaratimpengabdian dan bank sampahmitra di karanganyarakandapatmemberikanmanfaat yang lebihbaikapabilakegiataninididukung oleh komponen-komponenmasyarakatlainnya, terutamapihakwargaperumahan Joho BaruKaranganyar

\section{DAFTAR PUSTAKA}

Ade Octavia dkk. 2015. Pemberdayaan Masyarakat MelaluiOptimalisasi Program Bank SampahDenganBantuanTeknis dan ManajemenUsaha pada KSM Aneka Limbah dan KSM Maidanul Ula Kota Jambi. JurnalPengabdian Masyarakat, Vol 30 No.3. Hal 40-49.

http://www.alviescot.blogspot.com. 2015. PengolahanSampahOrganik

http://www.inginbisnis.com. 2015. DaurUlangSampahOrganikMenjadiPupukKompos

http://www.mazmuiz.blogspot.com. 2015 SampahOrganik Dan AnorganikManfaatBesertaContohnya.

Http://www.manfaat.co.id. 7 ManfaatLimbahAnorganikBagiKehidupan

http://www.kompas.com. 2016. SampahPotensiPenggerakRodaEkonomi

Justin, charlosdkk. 2005. Kewirausahaan. EdisiTerjemahan. Jakarta: PenerbitSalembaEmpat

Siska Maya dkk.2017. Pemberdayaan Masyarakat MelaluiPengelolaanSampahMenjadi Nilai Ekonomis dan Pembentukan Bank Sampah di KelurahanTanjung Barat. Proceeding of Community Development, Vol 1. Hal 157-161. 